\title{
Response of Peach, Plum and Almond to Water Restrictions Applied during Slowdown Periods of Fruit Growth
}

\author{
Rachid Razouk $^{1,2^{*}}$, Jamal Ibijbijen ${ }^{2}$, Abdellah Kajji ${ }^{1}$, Mohammed Karrou ${ }^{3}$ \\ ${ }^{1}$ Department of Agronomy, National Institute of Agronomic Research, Meknès, Morocco; ${ }^{2}$ Department of Biology, Faculty of Sci- \\ ences, University of Moulay Ismail, Meknès, Morocco; ${ }^{3}$ Integrated Water and Land Management Program, International Center for \\ Agricultural Research in the Dry Areas, Allepo, Syria. \\ Email: *razouk01@yahoo.fr
}

Received January $4^{\text {th }}, 2013$; revised February $12^{\text {th }}, 2013$; accepted February $26^{\text {th }}, 2013$

\begin{abstract}
Water restrictions management for fruit rosaceous during slowdown periods of fruit growth can increase water use efficiency and improve fruit quality without reducing significantly their yield. In this context, two water restriction levels were tested during four consecutive seasons (2007-2011) in peach, plum and almond trees during slowdown periods of fruit growth corresponding to Stage II for peach and plum and to Stages II and III for almond. Water was applied by drip irrigation to produce different water-application treatments of $50 \% \mathrm{ETc}\left(\mathrm{T}_{50}\right)$ and $75 \% \mathrm{ETc}\left(\mathrm{T}_{75}\right)$ of non-stressed trees irrigated at $100 \%$ ETc $\left(\mathrm{T}_{100}\right)$. The response of trees is presented only for the last season of the experiment (2010-2011) where the effect of the applied water stress is more pronounced. Results show that the effect of water restrictions varied depending on the species. Yield and fruit size were reduced significantly for peach only under treatment $\mathrm{T}_{50}$. Fruit quality was improved for this species with an increase of brix refractometric index and a decrease of acidity. These parameters were evolved in the same manner for plum but the observed differences were not significant. For almond, kernel quality remained unaffected by water restriction at $T_{75}$. However, the epidermal wrinkles of kernels were more embossed, in response to treatment $\mathrm{T}_{50}$, which affected their appearance. Except leaf area, the evolution of shoots growth, chlorophyll content and leaf temperature showed that the physiology of all species was affected by water stress created by the application of the two irrigation treatments but without profound influence, particularly in plum. In conclusion, irrigation-water may be economized during slowdown periods of fruit growth without major negative effect up to $25 \%$ ETc for peach and almond and up to $50 \%$ ETc for plum.
\end{abstract}

Keywords: Prunus Persica; Prunus Domestica; Prunus Dulcis; Water Stress; Fruit Yield; Fruit Quality; Vegetative Growth

\section{Introduction}

In Morocco, fruit rosaceous area is more than 208,000 hectares from which $84 \%$ are rosaceous with pits where almond, plum and peach trees represent $85 \%, 5 \%$ and $3 \%$ respectively. Production of these three species in the last three years ranged between 227,000 and 257,000 t/year [1]. The great variability in production is due to the occurrence of stressful climatic factors such as frost and drought $[2,3]$. These species, in particular almond, have known a real development during the last years thanks to efforts of the government (promotion of hydro-agricultural investments, distribution of plants, subsidies) and private initiatives [4].

Reduction of water resources and constant increase of

${ }^{*}$ Corresponding author. water requirements in agriculture, due to the competition with the other sectors, such as industry and drinking water [5], have lead to the concern of water savings. Therefore, it is necessary to develop techniques for improving plant-water use efficiency, especially for more water requiring species, like the majority of rosaceous trees [6,7], especially in regions where drought events are frequent, such as the case of Morocco [8]. This can be achieved through the effective management of irrigation, which consumes in Morocco 80 at $90 \%$ of available water resources [9].

Regulated deficit irrigation (RDI) is commonly used in fruit trees to reduce the amount of irrigation water applied without-or with only very small-reductions in yield [10]. RDI imposes a period of water stress that is controlled in terms of its intensity and the period of 
application [11]. This period corresponds generally to slow phases of fruit growth where a tree is relatively most tolerant to water deficit [12]. In almond tree, this phase occurs during Stages II and III of fruit development. However, in peach and plum trees, it is situated during stage II only [13].

RDI, if imposed judiciously, minimizes water use, decreases vegetative growth and pruning cost, and may improve fruit quality [14]. Studies of RDI in rosaceous trees remains very limited under Moroccan conditions. The adoption of the findings obtained in similar experiments conducted in other countries [15-17] is not justified because the results are not conclusive, probably, because of different experimental conditions and used genotype. The studies on RDI are specific to a particular ecosystem. It must consider the productions levels and their stability, physiological behavior of trees and fruits quality. For these reasons the aim of this paper was to test various levels of water stress applied during slowdown periods of fruit growth of mature peach, plum and almond trees. The evaluation of trees response was based on measurement of yield, fruits quality, biometrics characteristics of fruits and vegetative growth.

\section{Materials and Methods}

\subsection{Experimental Design}

The experiment was carried out during four consecutive seasons (2007-2011) in the Taoujdate experiment station of the National Institute of Agronomic Research (INRA) located $40 \mathrm{~km}$ North of Meknes city in Morocco at $33^{\circ} 56^{\prime} \mathrm{E}, 5^{\circ} 13^{\prime} \mathrm{N}$; $499 \mathrm{~m}$. Meteorological data of the site are presented in Figure 1 where it is shown that rainfall deficit is more marked between May and September with a peak in July and August. The soil is sandy clay with an average of $3 \% \mathrm{CaCO}_{3}$, rich in organic matter, with an average of $2.51 \%$ in the top soil surface layer $(0-30$ $\mathrm{cm})$. The soil $\mathrm{pH}$ is slightly alkaline (7.7), the soil is not saline (average EC around $0.07 \mathrm{~ms} \cdot \mathrm{cm}^{-1}$ in the top 60 $\mathrm{cm})$.

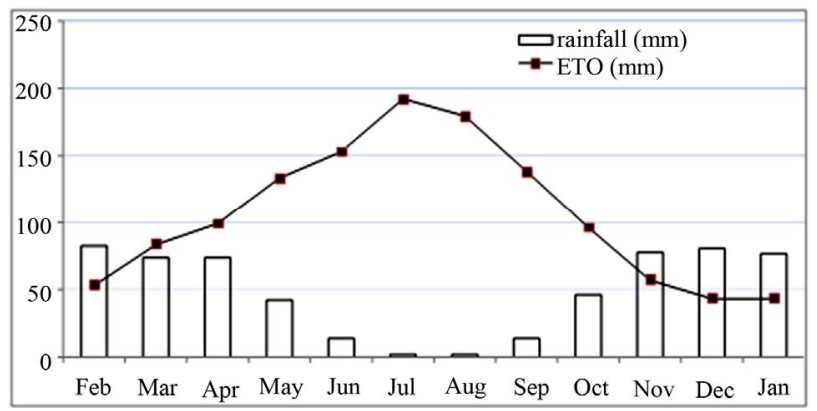

Figure 1. Monthly rainfall in 2010-2011 and Hargreaves evapotranspiration calculated using data for 11 last years from meteorological station in field.
For each species, peach (Prunus Persica, cv, JH-Hall), plum (Prunus Domestica, cv, Stanley) and almond (Prunus Dulcis, cv, Tuono), planted in 2004 in parallel lines spaced by $5 \times 3 \mathrm{~m}, 15$ trees were used: The trees were trimmed as goblet canopy shape. During the experiment, all the trees of each species were pruned, fertilized and managed similarly, except for irrigation where different water levels were applied.

Crop evapotranspiration (ETc) was estimated as the product of reference evapotranspiration (ETo) obtained with the Hargreaves model [18] and the crop coefficients recommended by FAO adjusted to planting density and foliage dimensions using a reduction coefficient $(\mathrm{Kr})$ recommended for almond tree: $\mathrm{Kr}=\pi \mathrm{D}^{2} \mathrm{~N} / 20000$ where " $\mathrm{D}$ " is the average of foliage diameters and " $\mathrm{N}$ " is planting density [19]. ETo was determined using climate data of the last eleven years, collected from the INRA meteorological station located in the experimental field.

The irrigation treatments were applied during four consecutive seasons (2007-2011) at slowdown period of fruit growth for each species by supplying different fractions of crop water requirements (ETc). This period was determined for each species under full-irrigation $(100 \%$ $\mathrm{ET}_{0}$ ) by weekly in situ measurement of fruits diameter, on six fruiting branches, from fruit set to fruit maturity during three seasons (2007-2010). In parallel, shoots elongation was measured per linear meter on the same fruiting branches to provide explanations of results, especially for vegetative growth. In the fourth season (20102011), two irrigation treatments, 50\% ETc $\left(\mathrm{T}_{50}\right)$ and $75 \%$ ETc $\left(\mathrm{T}_{75}\right)$ were compared to $100 \%$ ETc $\left(\mathrm{T}_{100}\right)$, imposed during slowdown period of fruit-growth for each species. Irrigation water was applied daily using drip system with two emitters per plant. Water quantity was regulated by watering duration.

For each species, the experimental design was a randomized complete block, with three replications. Each of the three block consisted of five trees. The three central trees of each block were selected for application of water treatments, while the surrounding trees were considered as "guard tree" borders.

\subsection{Measurements}

Generally, response of adult trees to regulated deficit irrigation is not detected in the first year, but it appears after a few years, because of reserves mobilized in wood and large volume explored by roots [20,21]. For this reason, different parameters describing these effects were measured during the fourth season of stress, in 20102011.

\subsubsection{Vegetative Growth and Physiological Measurements}

Effect of the applied water stress to vegetative growth 
was evaluated by measurement of annual shoot elongation and leaf area in early November. Average of annual shoot elongation was estimated on all shoots worn by four fruiting two-year-old branches per replication (twelve branches per treatment) chosen at the same height in four sides of trees. Shoot length was reported in linear meter of fruiting branches for eliminate variability that may due to their vigor. Leaf area was measured on all leaves cut without petioles from ten shoots with almost the same length selected randomly per replication. After cutting, leaves were placed in plastic bags and were transported immediately to the laboratory. The area of each leaf was measured using a leaf area meter (adc, bioscientific Ltd) calibrated to $0.01 \mathrm{~cm}^{2}$.

Leaf temperature and chlorophyll content index were measured weekly, in the morning at $11 \mathrm{~h}$, from the beginning of water treatments to harvest on six marked leaves per replication for each species, using an infrared thermometer and SPAD chlorophyll-meter. The leaves were selected on shoots exposed to the north and having approximately equal lengths.

\subsubsection{Biometric Parameters of Fruit and Yield}

At fruit maturity of each species, samples of fruits, approximately $3 \mathrm{~kg}$ each, were collected from randomly ten selected fruiting branches per replication to evaluate the following parameters: fruit and pit weight, fruit and pit dimensions (length and width). This method of sampling fruits takes into consideration the variability of fruit size in a tree. After sampling fruits, each tree was manually harvested and weighed in the field. For eliminating the differences in yield due to variability of tree vigor, yield values were determined per $\mathrm{cm}^{2}$ of trunk section area estimated by measuring trunk-circumference.

\subsubsection{Fruit Quality Measurements}

Effect of the water treatments on fruit quality was evaluated for peach and plum by measurements of sugar content, acidity, $\mathrm{pH}$ and water content. While for almond kernel, it was assessed by measurement of number and relief of epidermal wrinkles. All the parameters were measured on ten mature fruits per replication.

On pulp of peach and plum, sugar content was determined in drops of fruit juice by measurements of refractometric index ( ${ }^{\circ}$ Brix) using a refractometer. Acidity was determined by titration of free acids and measurements of $\mathrm{pH}$ following methods reported by Lichou [22]. Indeed, $5 \mathrm{~g}$ of pulp is mixed in $50 \mathrm{ml}$ of distilled water and titrated by sodium hydroxide $0.1 \mathrm{~N}$ under continuous agitation until the $\mathrm{pH}$ value reached 8.1. Thus, acidity (Ac) is given by the relationship: $\mathrm{Ac}=\mathrm{V} \times \mathrm{C} \times 100 / \mathrm{m}$ where " $\mathrm{V}$ " is the volume of sodium hydroxide used in $\mathrm{ml}$, " $\mathrm{C}$ " is the concentration of sodium hydroxide in $\mathrm{mol} \cdot \mathrm{l}^{-1}$ and " $\mathrm{m}$ " is the mass of fresh pulp dosed in $\mathrm{g}$. Whereas pulp
$\mathrm{pH}$ was determined directly by soaking the $\mathrm{pH}$-meter electrode in crushed pulp. Water content was measured by drying fruits pulp at $80^{\circ} \mathrm{C}$ during $48 \mathrm{~h}$. On almond kernels, epidermal wrinkles were counted visually and their relief has been evaluated by awarding points from 0 to 5 .

\subsubsection{Statistical Analysis}

Data were analyzed by analysis of variance (ANOVA) using the SPSS software (version 17.0). Mean comparisons were performed using Dunett's test to compare deficit irrigation to full irrigation and student's test to compare between $\mathrm{T}_{50}$ and $\mathrm{T}_{75}$.

\section{Results and Discussion}

\subsection{Slow Growth Periods}

In peach and plum trees, fruit-growth slowdown corresponds to pit hardening stage (stage II). However in almond tree, it included pit hardening and final stage of fruit growth (stages II and III) [23]. Based on monitoring of fruit diameter, this period is located at different periods in the three species (Figure 2). In almond tree, fruitgrowth slowdown was observed during four months, from April 30 to harvest in September 04. In peach tree, fruit-growth slowdown was recorded during two weeks only, between May 25 and June 10. While in plum tree, fruit-growth slowdown was observed during five weeks, from May 25 to July 01. During the slowdown periods, outer dimensions of the fruit change little, increasing significantly by different magnitudes depending to species. Indeed during these periods, fruit diameter was increased under full irrigation $\mathrm{T}_{100}$ by $26 \%$ for peach, $12 \%$ for plum and $8 \%$ for almond, equivalent respectively to a daily growth of $1.73 \% \cdot \mathrm{d}^{-1}, 0.34 \% \cdot \mathrm{d}^{-1}$ and $0.06 \% \cdot \mathrm{d}^{-1}$.

Shoot growth began when fruit diameter reached $17 \%$ for almond, $27 \%$ for peach and $13 \%$ for plum. This fruit production came from floral receptacle and previous reserves of trees. During slowdown period of fruit growth, shoot growth is however rapid. During this period, shoot grows by around $133 \%, 46 \%$ and $88 \%$ under full irrigation $\mathrm{T}_{100}$ respectively in peach, plum and almond. Slowdown period of shoot growth began after two weeks of pit hardening stage in the three species. At this date, fruit diameter reached $92 \%$ for peach, $85 \%$ for plum and $99 \%$ for almond.

Based on duration of slowdown period of fruit growth, it appears clear that application of RDI during these periods seems more economically important for almond and plum. However for peach, two weeks of saving water seems insufficient period to generate a considerable economic impact. The impact would be important using later varieties, for which kernel hardens during a longer period [24]. Fruit growth rate during slowdown periods 

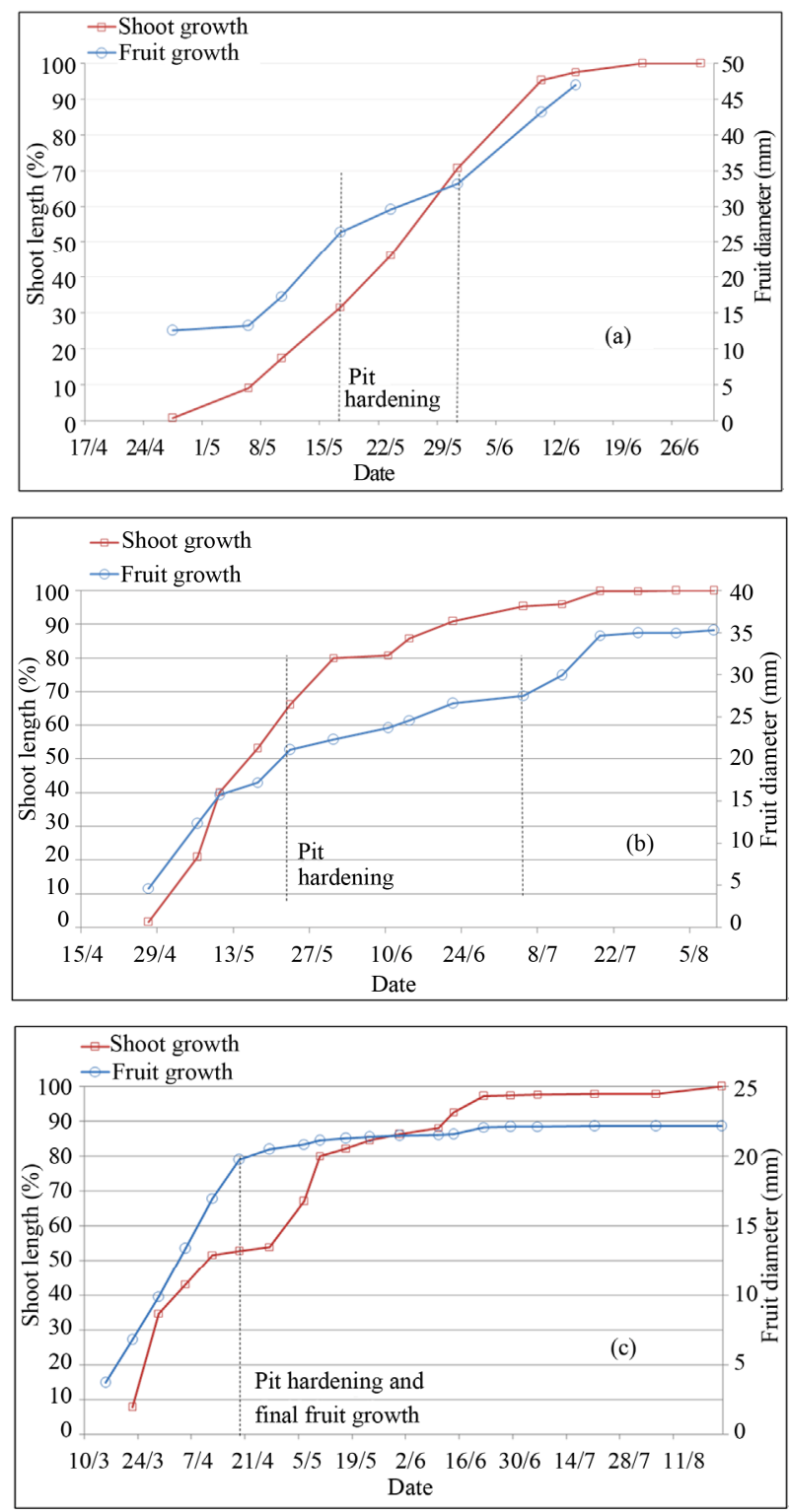

Figure 2. Shoot and fruit growth for peach (a), plum (b) and almond (c) under full irrigation $\left(T_{100}\right)$.

may indicate the percentage of fruit weight on which act water restrictions, showing that peach remains the most sensitive fruit, followed by plum and almond, whose around quarter of fruit size is determined during this period. The coincidence of slow fruit growth with rapid shoot growth makes that the RDI strategy in experimenttation may be used to control excessive vegetative growth of trees. This finding has been concluded by other authors [15].

\subsection{Shoot Length and Leaf Area}

Shoot growth of all tested species was very affected by RDI treatments (Table 1). The differences between values of final shoot length under RDI treatments and those obtained under treatment $\mathrm{T}_{100}$ showed that the applied water stress had a more pronounced effect on almond, followed by plum and then by peach. Based on Student's test for each species, the two RDI treatments reduced shoot length by the same magnitude, by an average of $63 \%, 45 \%$ and $42 \%$ respectively in almond, plum and peach. However, Dunett's test revealed that the effect is significantly more pronounced under treatment $T_{50}$ in peach and plum trees for which shoot length was reduced in comparison to treatment $\mathrm{T}_{75}$ respectively by $19 \%$ and $7 \%$. For leaf area, although its values decreased under the applied water stress, the effect was not significant.

Therefore, it is clear that moderate water stress applied during the slowdown period of fruit growth restricts shoots growth. This finding is important because it means that water stress applied under these conditions will limit effects of competition exerted by shoot growth against fruit growth. The effect observed does not corroborate with those obtained by other authors, it appears that RDI effect on shoot elongation varies with climatic conditions and used cultivar. In Spain, it is found that shoot length in peach cv. Sudanell under water treatment similar to $\mathrm{T}_{50}$ does not exceed $25 \%$ [15]. In Italy, there was no significant effect of RDI applied during stage II of plum development, cv. Fortune, on shoot growth [25]. However, limitation of shoot growth does not significantly affect leaf area. RDI effect on leaf growth is compensated by reduction of shoot length implicitly reducing their number.

Shoot growth reduction is an adaptive mechanism which reduces tree transpiration [26]. It results from several reversible mechanisms such as decrease of cell division speed [27], rigidity of cellular wall limiting cell growth [28] and decrease of cell turgor [29]. However, there is a consensus that reduction of vegetative growth is not a passive consequence of water deficiency in cells, but is rather controlled by trees [30]. It emerges that shoot growth reduction does not necessarily imply a water stress in cells.

Table 1. Shoot length and leaf area under different irrigation treatments.

\begin{tabular}{ccccc}
\hline & & Peach & Plum & Almond \\
\hline & $\mathrm{T}_{100}$ & $295.0 \pm 2.8 \mathrm{a}$ & $200.3 \pm 6.0 \mathrm{a}$ & $298.3 \pm 88.6 \mathrm{a}$ \\
$\begin{array}{c}\text { Shoot length } \\
\left(\mathrm{cm} \cdot \mathrm{Lm}^{-1}\right)\end{array}$ & $\mathrm{T}_{75}$ & $189.0 \pm 48.4 \mathrm{~b}$ & $117.3 \pm 19.3^{*} \mathrm{~b}$ & $114.3 \pm 28.5^{*} \mathrm{~b}$ \\
& $\mathrm{~T}_{50}$ & $153.3 \pm 0.3^{*} \mathrm{~b}$ & $102.0 \pm 12.7^{* *} \mathrm{~b}$ & $103.2 \pm 21.9^{*} \mathrm{~b}$ \\
& $\mathrm{~T}_{100}$ & $50.6 \pm 4.8$ & $19.4 \pm 1.2$ & $11.8 \pm 0.7$ \\
$\begin{array}{c}\text { Leaf area } \\
\left(\mathrm{cm}^{2}\right)\end{array}$ & $\mathrm{T}_{75}$ & $49.8 \pm 2.9$ & $19.4 \pm 1.3$ & $10.5 \pm 2.3$ \\
& $\mathrm{~T}_{50}$ & $46.7 \pm 4.0$ & $19.3 \pm 0.9$ & $9.7 \pm 0.6$ \\
\hline
\end{tabular}

Lm: linear meter; ${ }^{* *}$ : Significant difference at $99 \%$ using Dunett's test in comparison to treatment " $\mathrm{T}_{100}$ "; ": Significant difference at $95 \%$ using Dunett's test in comparison to treatment " $\mathrm{T}_{100}$ ". 


\subsection{Chlorophyll Content}

Chlorophyll content is an important indicator to assess the effect of water stress on the physiological behavior of trees because of its role in solar energy absorption which is necessary for photosynthesis [31]. Chlorophyll concentration index measured using the chlorophyll meter indicated that there were significant differences in variation of chlorophyll content, induced by water restrictions. After the application of water restrictions, chlorophyll content decreased very much for all species and began to increase to reach the initial values at the end of water restrictions for peach and before this date for plum and almond (Figure 3). The decrease of chlorophyll content was more pronounced under treatment $T_{50}$ whose effect was extended to stage III of fruit growth.

Certainly, reduction of chlorophyll content under water stress conditions is related to decrease in assimilation and translocation of nitrogen [32]. Indeed, water deficit induced a nitrogen deficit which comes mainly from reductions in nitrogen flow at the roots, and secondarily
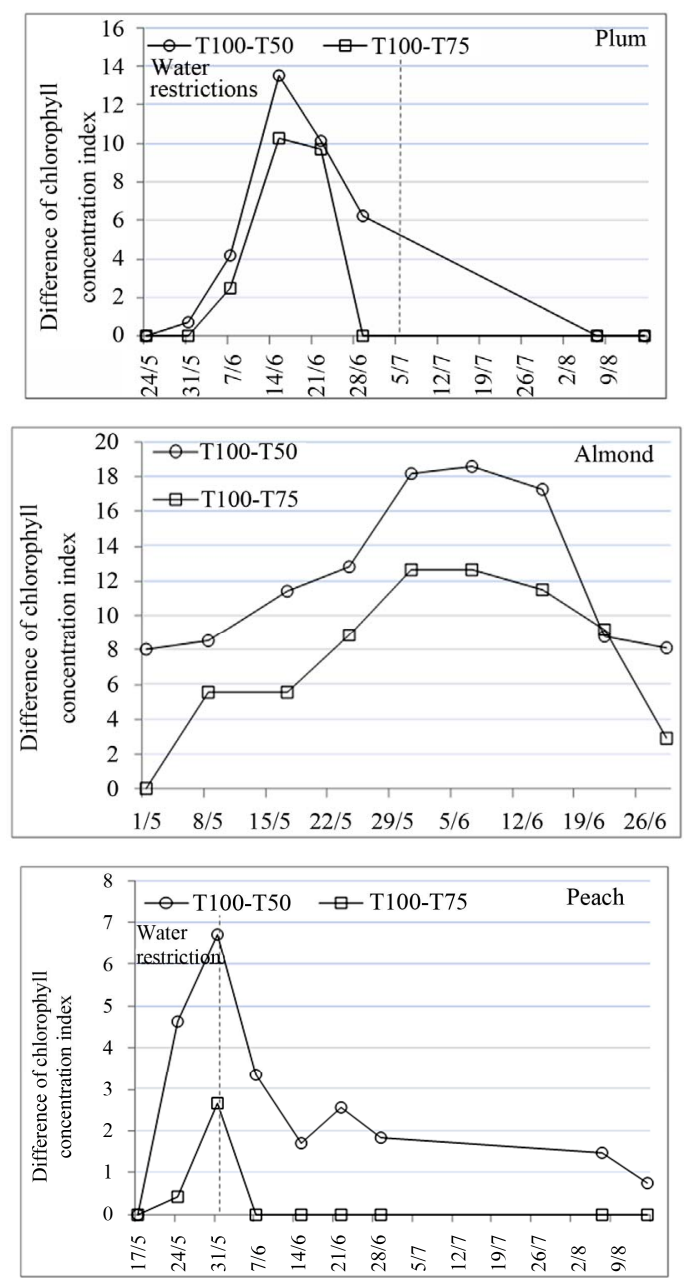

Figure 3. Effect of water restrictions on chlorophyll concentration index for peach, plum and almond. from capacity reductions of root absorption and reduction of transport between leaves and roots due to transpiration feebleness [30].

\subsection{Leaf Temperature and Stress Degree Day}

Leaf temperature features prominently among biophysical parameters commonly used to evaluate plant water status [33]. Water restrictions increased significantly leaf temperature for all species during and even after their application. For peach, the average of increase was $3.2^{\circ} \mathrm{C}$ under treatment $\mathrm{T}_{50}$ and $2.1^{\circ} \mathrm{C}$ under treatment $\mathrm{T}_{75}$, while for plum and almond, the applied water restrictions increased leaf temperature with the same magnitude of $2.2^{\circ} \mathrm{C}$ (Table 2). Therefore, it is clear that the water deficit is associated with thermal stress because of reductions in transpiration.

The linear relationship between leaf temperature and air temperature was also influenced by water restrictions. Under full irrigation $T_{100}$, the relationship between the two temperatures is not significant, but under the water restrictions the correlation coefficient changes to significant values. This same finding was obtained by Helyes et al. in haricot [34]. In fact, under full irrigation, the leaf temperature was not very influenced by air temperature because of importance of steam water in leaves surface. However, under water restriction, transpiration and steam water in leaves surface weakened and make accordingly leaves more exposed to air temperature changes.

Stress degree day values (SDD), corresponding to the difference between leaf temperature and air temperature, showed that in some days under water stress, particularly where air temperature was relatively high, steam water of transpiration was unable to cool leaf surface making leaf temperature exceeded air temperature. Accumulated SDD values at harvest were high and significant for all species under the two tested water restrictions. Particularly for peach, where fruit yield was affected by treatment $\mathrm{T}_{50}$, it was estimated that a $1^{\circ} \mathrm{C}$ higher SDD value might cause $105.4 \mathrm{~kg} \cdot \mathrm{ha}^{-1}$ yield losses. However, for plum and almond, SDD values variation did not have a significant effect on fruit yield.

Figure 4 shows the evolution of accumulated SDD values from the beginning of water restrictions to harvest. The curves obtained indicate that the effect of water stress started during the first week of its application; but, it increased rapidly after one week for peach and after three weeks for plum and almond even during the period following the end of water restrictions.

\subsection{Fruit Weight, Yield and Water Use Efficiency}

The effect of water restrictions on final fruit weight and dimensions was evaluated using Dunett's test (Table 3). 
Table 2. Effect of irrigation treatments on SDD values and on relationship between leaf and air temperatures for peach, plum and almond trees.

\begin{tabular}{|c|c|c|c|c|c|c|c|c|}
\hline & & Number of days & Air temp. $\left({ }^{\circ} \mathrm{C}\right)$ & Leaf temp. $\left({ }^{\circ} \mathrm{C}\right)$ & $\operatorname{SDD}\left({ }^{\circ} \mathrm{C}\right)$ & $\begin{array}{c}\text { Cumulative SDD } \\
\text { values }\left({ }^{\circ} \mathrm{C}\right)\end{array}$ & Regression function & $r^{2}$ \\
\hline \multirow{3}{*}{ Peach } & $\mathrm{T}_{100}$ & 29 & 34.5 & $29.2 \mathrm{c}$ & $5.3 \mathrm{a}$ & - & $y=0.030 x+28.1$ & 0.310 \\
\hline & $\mathrm{T}_{75}$ & 29 & 34.5 & $31.3 \mathrm{~b}$ & $3.1 \mathrm{~b}$ & 49.0 & $y=0.254 x+22.6$ & 0.651 \\
\hline & $\mathrm{T}_{50}$ & 29 & 34.5 & $32.4 \mathrm{a}$ & $2.0 \mathrm{c}$ & 73.3 & $y=0.743 x+6.8$ & $0.810^{* *}$ \\
\hline \multirow{3}{*}{ Plum } & $\mathrm{T}_{100}$ & 101 & 34.5 & $26.3 \mathrm{c}$ & $8.2 \mathrm{a}$ & - & $y=1.353 x-20.3$ & 0.518 \\
\hline & $\mathrm{T}_{75}$ & 101 & 34.5 & $28.0 \mathrm{a}$ & $6.5 \mathrm{~b}$ & 223.6 & $y=1.496 x-23.6$ & 0.623 \\
\hline & $\mathrm{T}_{50}$ & 101 & 34.5 & $29.0 \mathrm{a}$ & $5.5 \mathrm{~b}$ & 109.3 & $y=1.409 x-19.6$ & $0.667^{*}$ \\
\hline \multirow{3}{*}{ Almond } & $\mathrm{T}_{100}$ & 123 & 34.5 & $26.8 \mathrm{~b}$ & $7.6 \mathrm{a}$ & - & $y=0.984 x-7.1$ & 0.432 \\
\hline & $\mathrm{T}_{75}$ & 123 & 34.5 & $28.4 \mathrm{a}$ & $6.0 \mathrm{~b}$ & 252.1 & $y=1.558 x-25.2$ & 0.554 \\
\hline & $\mathrm{T}_{50}$ & 123 & 34.5 & $29.6 \mathrm{a}$ & $4.8 \mathrm{~b}$ & 135.2 & $y=1.238 x-13.0$ & $0.631^{*}$ \\
\hline
\end{tabular}

Table 3. Peach, plum and almond fruit characteristics under different irrigation treatments.

\begin{tabular}{ccccccc}
\hline & & Fruit weight $(\mathrm{g})$ & Pit weight $(\mathrm{g})$ & Pit/fruit $(\mathrm{g} / \mathrm{g})$ & Length $(\mathrm{cm})$ & Width $(\mathrm{cm})$ \\
\hline \multirow{4}{*}{ Peach } & $\mathrm{T}_{100}$ & $118.7 \pm 3.7$ & $6.54 \pm 0.4$ & $0.06 \pm 0.0$ & $5.80 \pm 0.5$ & $6.31 \pm 1.0$ \\
& $\mathrm{~T}_{75}$ & $106.4 \pm 4.9$ & $6.07 \pm 0.2$ & $0.06 \pm 0.0$ & $5.68 \pm 1.1$ & $5.87 \pm 1.2^{*}$ \\
& $\mathrm{~T}_{50}$ & $90.2 \pm 4.5^{* *}$ & $4.60 \pm 0.2^{* *}$ & $0.06 \pm 0.0$ & $5.32 \pm 0.8^{* *}$ & $5.52 \pm 0.9^{* *}$ \\
& $\mathrm{~T}_{100}$ & $37.7 \pm 1.1$ & $2.09 \pm 0.1$ & $0.06 \pm 0.0$ & $5.20 \pm 0.3$ & $3.58 \pm 0.7$ \\
\multirow{5}{*}{ Plum } & $\mathrm{T}_{75}$ & $35.4 \pm 1.3$ & $2.00 \pm 0.6$ & $0.06 \pm 0.0$ & $5.10 \pm 0.8$ & $3.44 \pm 0.5$ \\
& $\mathrm{~T}_{50}$ & $35.0 \pm 0.8$ & $1.78 \pm 0.1$ & $0.06 \pm 0.0$ & $5.06 \pm 0.4$ & $3.46 \pm 0.5$ \\
& $\mathrm{~T}_{100}$ & $2.65 \pm 0.0$ & $1.12 \pm 0.0$ & $0.42 \pm 0.1$ & $2.86 \pm 0.5$ & $1.54 \pm 0.2$ \\
& $\mathrm{~T}_{75}$ & $2.63 \pm 0.0$ & $1.04 \pm 0.0$ & $0.39 \pm 0.0$ & $2.82 \pm 0.5$ & $1.52 \pm 0.1$ \\
& $\mathrm{~T}_{50}$ & $2.57 \pm 0.0$ & $1.01 \pm 0.3$ & $0.39 \pm 0.1$ & $2.93 \pm 0.2$ & $1.56 \pm 0.2$ \\
\hline
\end{tabular}

Width measured with the suture in the middle.

The difference was significant only for peach under treatment $\mathrm{T}_{50}$ which reduced fruit and pit weights respectively by $24 \%$ and $29.6 \%$. Reduction of peach weight exceeded the rate of fruit growth observed during pit hardening stage (Figure 2), proving that the effect of this water stress level was also extended to the final stage of fruit growth. This reduction resulted certainly from simultaneous regression of pulp and pit growth confirmed by the non-significant differences in the ratio of "pit weight/fruit weight". Sensitivity of peach to water restriction $\mathrm{T}_{50}$ may be linked to fruit growth rate during stage II where water stress was applied, which is relatively high for peach compared to plum and almond (Figure 2). In plum and almond, there was a slight tendency for diminished fruit weight under RDI treatments but the differences are not significant. This result was related to fruit growth during period of water stress (Figure 2) which is less important for these two species compared to peach.

The variations in yield levels were linked in large part to fruit weight variation because water treatments were started after fruit set and that there were no differences in the physiological downfall of fruits. In all tested species, fruit yield obtained under RDI treatment $\mathrm{T}_{75}$ was statistically equal to that obtained under full irrigation $T_{100}$. The same result was obtained with RDI treatment $\mathrm{T}_{50}$ in almond and plum trees. However, in peach, this last treatment affected significantly fruit yield which was reduced by $41 \%$ (Table 4 ). This decrease of yield would be also due to variation of trees vigor whose effect was separated according to yield values per $\mathrm{cm}^{2}$ of trunk section. Thereby, the decrease of peach yield due to water stress only is estimated at $25 \%$.

The observed changes in fruit weight and yield of peach are in contradiction with results obtained by others authors $[15,35,36]$ which reported that RDI applied during stage II of fruit development did have no effect on fruit weight and yield even at a very stressful level 35\% ETc. In others studies, there is an increase in fruit weight and yield when trees were subjected to RDI during stage II $[37,38]$. For almond, the results found corroborate with these obtained by others authors $[39,40]$ which concluded that RDI decreased kernel water content without significant effect on fruit weight at maturity. This result is in contradiction with these obtained by others researchers which reported that almond productivity de- 

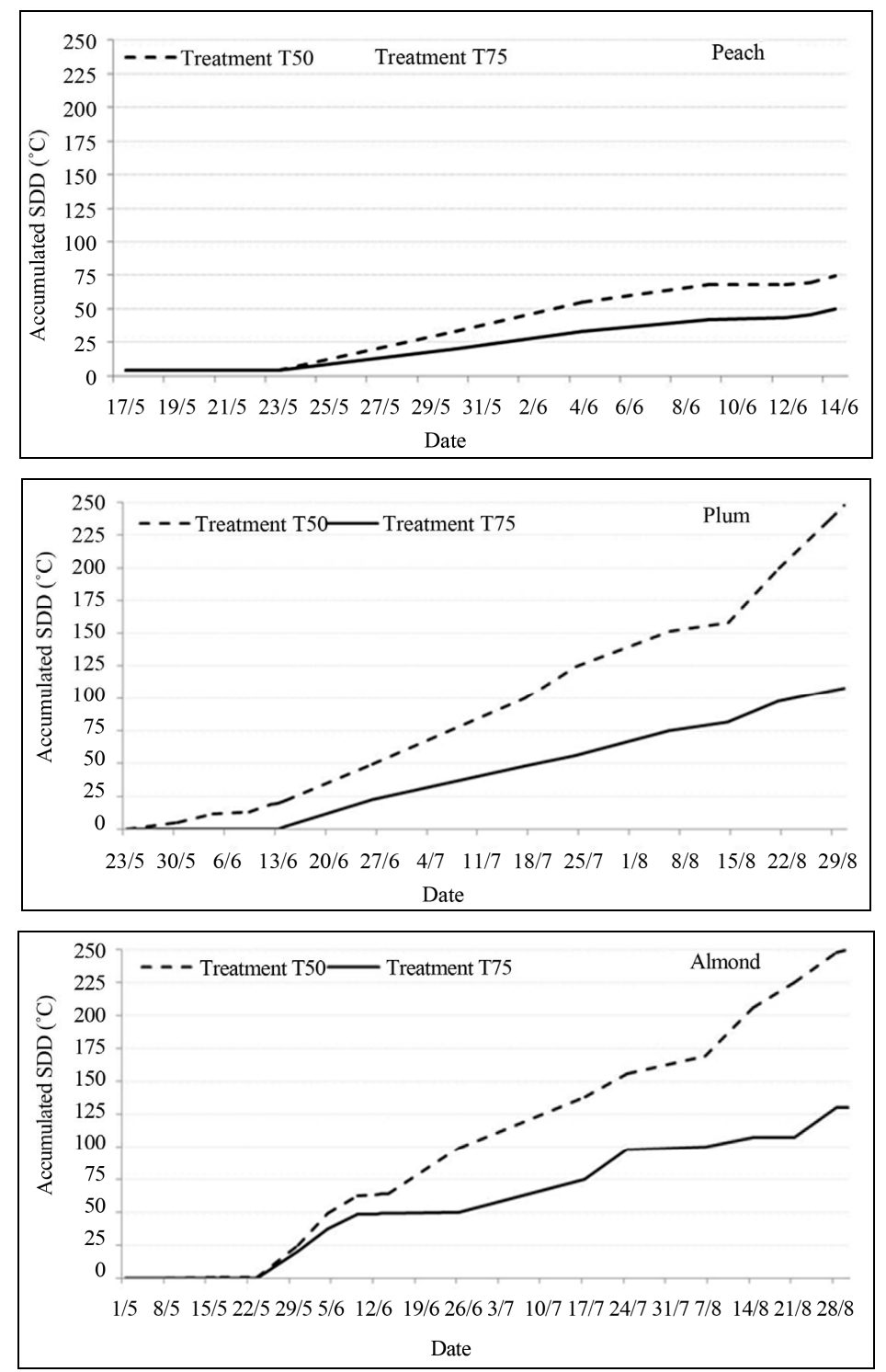

Figure 4. Accumulated SDD values from pit hardening to harvest under water restrictions for peach, plum and almond (SDD = Tl - Ta, where the positives values were accumulated).

crease when trees received $30 \%$ less water than full irrigation $[41,42]$. Likewise, for plum, the same result was obtained by Battilani [25] and Intrigliolo and Castel [43]. However, in other experiments, it was concluded that fruit weight and yield increase when trees subjected to RDI during stage II [44]. The contradictory results may be due to differences in soil texture, soil depth and water capacity of the soil.

Generally, water use efficiency (WUE) was improved significantly by application of RDI treatments. In peach tree, under treatment $\mathrm{T}_{75}$, which had no effect on fruit yield, ensured an improvement of WUE by $36 \%$ compared to treatment $\mathrm{T}_{100}$ based on values per $\mathrm{cm}^{2}$ of trunk section. The same improvement of WUE was ensured by treatment $\mathrm{T}_{50}$ under which fruit yield decreased. In plum tree, the tow treatments $T_{75}$ and $T_{50}$ have improved significantly WUE by the same amplitude by an average of $41 \%$. Contrary, in almond tree, the two treatments affected differently WUE values. Indeed, it was improved under treatment $\mathrm{T}_{75}$ by $15 \%$ and significantly better under treatment $\mathrm{T}_{50}$ by $30 \%$.

\subsection{Fruit Quality}

Table 5 shows that water content for peach and plum was not affected by the imposed water restrictions. This same finding was obtained by few authors [35,44]. RDI decreases fruit water content during stage where it is applied, but after its elimination, water content regains values obtained under full irrigation [41]. No changes in fruit water content indicate that variations in fruit 
Table 4. Fruit yield and water use efficiency under different irrigation treatments on peach, almond and plum trees.

\begin{tabular}{|c|c|c|c|c|c|}
\hline & & Fruit yield $\left(\mathrm{kg} \cdot\right.$ tree $\left.^{-1}\right)$ & Yield efficiency $\left(\mathrm{g} \cdot \mathrm{cm}^{-2} \cdot \mathrm{TS}\right)$ & WUE $\left(\mathrm{m}^{3} \cdot \mathrm{kg}^{-1} \cdot\right.$ tree $\left.^{-1}\right)$ & WUE $\left(\mathrm{L} \cdot \mathrm{g}^{-1} \cdot \mathrm{cm}^{-2} \cdot \mathrm{TS}\right)$ \\
\hline \multirow{3}{*}{ Peach } & $\mathrm{T}_{100}$ & $28.3 \pm 2.3 \mathrm{a}$ & $142.9 \pm 7.8 \mathrm{a}$ & $0.11 \pm 0.01 \mathrm{a}$ & $16.9 \pm 0.6 \mathrm{a}$ \\
\hline & $\mathrm{T}_{75}$ & $26.7 \pm 1.2 \mathrm{a}$ & $133.9 \pm 6.0 \mathrm{a}$ & $0.07 \pm 0.03^{*} \mathrm{~b}$ & $14.1 \pm 0.6 \mathrm{a}$ \\
\hline & $\mathrm{T}_{50}$ & $16.7 \pm 2.0^{*} \mathrm{~b}$ & $107.2 \pm 4.9^{*} \mathrm{~b}$ & $0.07 \pm 0.01^{*} \mathrm{~b}$ & $13.8 \pm 0.9^{*} \mathrm{~b}$ \\
\hline \multirow{3}{*}{ Plum } & $\mathrm{T}_{100}$ & $33.9 \pm 4.6$ & $223.9 \pm 32.8$ & $0.17 \pm 0.01 \mathrm{a}$ & $16.4 \pm 2.1 \mathrm{a}$ \\
\hline & $\mathrm{T}_{75}$ & $31.7 \pm 1.6$ & $234.0 \pm 15.4$ & $0.10 \pm 0.04^{*} \mathrm{~b}$ & $15.2 \pm 2.5^{*} \mathrm{~b}$ \\
\hline & $\mathrm{T}_{50}$ & $30.1 \pm 1.2$ & $219.6 \pm 36.3$ & $0.10 \pm 0.05^{*} \mathrm{~b}$ & $14.8 \pm 0.9^{*} \mathrm{~b}$ \\
\hline \multirow{3}{*}{ Almond } & $\mathrm{T}_{100}$ & $10.6 \pm 0.9$ & $60.8 \pm 2.6$ & $0.33 \pm 0.03 \mathrm{a}$ & $58.2 \pm 31.0 \mathrm{a}$ \\
\hline & $\mathrm{T}_{75}$ & $10.0 \pm 1.0$ & $57.7 \pm 7.4$ & $0.28 \pm 0.02^{*} \mathrm{~b}$ & $50.7 \pm 26.9^{*} \mathrm{~b}$ \\
\hline & $\mathrm{T}_{50}$ & $9.8 \pm 1.7$ & $54.3 \pm 9.5$ & $0.23 \pm 0.03^{*} \mathrm{c}$ & $46.9 \pm 34.8^{*} \mathrm{c}$ \\
\hline
\end{tabular}

$\mathrm{cm}^{-2} \cdot \mathrm{TS}: \mathrm{cm}^{2}$ of trunk section; WUE: water use efficiency.

Table 5. Fruit quality parameters for peach, plum and almond under different irrigation treatments.

\begin{tabular}{|c|c|c|c|c|}
\hline & & $\mathrm{T}_{100}$ & $\mathrm{~T}_{75}$ & $\mathrm{~T}_{50}$ \\
\hline \multirow{3}{*}{ Peach } & ${ }^{\circ}$ Brix & $12.23 \pm 0.1 \mathrm{~b}$ & $13.50 \pm 0.1^{* *} \mathrm{a}$ & $13.66 \pm 0.1^{* *} \mathrm{a}$ \\
\hline & Acidity (meq.100gFM ${ }^{-1}$ ) & $22.01 \pm 0.1 \mathrm{a}$ & $20.01 \pm 0.1^{* *} \mathrm{~b}$ & $16.40 \pm 0.1^{* *} \mathrm{c}$ \\
\hline & $\mathrm{pH}$ & $7.2 \pm 0.0 \mathrm{a}$ & $7.1 \pm 0.0 \mathrm{a}$ & $6.9 \pm 0.0^{*} \mathrm{~b}$ \\
\hline \multirow{5}{*}{ Plum } & Humidity (\%) & $81.5 \pm 0.7$ & $81.2 \pm 1.2$ & $81.2 \pm 1.2$ \\
\hline & ${ }^{\circ}$ Brix & $22.76 \pm 0.3$ & $24.66 \pm 1.3$ & $25.23 \pm 0.7$ \\
\hline & Acidity (meq.100gFM ${ }^{-1}$ ) & $5.30 \pm 0.0$ & $4.83 \pm 0.2$ & $4.63 \pm 0.3$ \\
\hline & $\mathrm{pH}$ & $7.1 \pm 0.1$ & $6.6 \pm 0.1$ & $6.6 \pm 0.1$ \\
\hline & Humidity (\%) & $74.9 \pm 0.8$ & $74.9 \pm 0.8$ & $74.9 \pm 0.8$ \\
\hline \multirow{2}{*}{ Almond } & Wrinkles/kernel & $10.0 \pm 0.5$ & $11.0 \pm 0.2$ & $11.1 \pm 0.5$ \\
\hline & Wrinkles relief (points/5) & $2.2 \pm 0.1 \mathrm{~b}$ & $2.2 \pm 0.1 \mathrm{~b}$ & $3.0 \pm 0.0^{* *} \mathrm{a}$ \\
\hline
\end{tabular}

chemical parameters were not due to their concentration ratio with water content, but rather to changes in fruit metabolic activity.

The acidity and sugar content remained unchanged with the variation of irrigation treatments in plum, but significantly affected in peach. The relationship between increase of sugar content in peach and those of water stress level is not linear. In fact, the two stress treatments $\mathrm{T}_{50}$ and $\mathrm{T}_{75}$ increased sugar content by the same rate, by an average of $1.35^{\circ}$ Brix. However, the acidity decreased almost linearly with water stress increase, with significant correlation coefficient $\mathrm{r}$ of 0.78 . The decrease rate was $9.1 \%$ under treatment $\mathrm{T}_{75}$ and $25.4 \%$ under treatment $\mathrm{T}_{50}$ comparatively to treatment $\mathrm{T}_{100}$. Changes observed in peach quality corroborate with results found by others authors $[15,45,46]$ who reported that RDI applied during Stage II induces an improvement of fruit quality by increasing sugar concentration accompanied by a decrease of organic acids concentration.

Almond kernel quality, evaluated based on observation of epidermal wrinkles, changed with variation of water stress level. Wrinkles did not change in number, but their relief was increased, damaging almond nut quality by the deterioration of their appearance. However, significant variation of wrinkles relief was obtained only under the most stressful treatment $\mathrm{T}_{50}$ increasing the relief by $36 \%$. The accentuation of wrinkles relief under RDI treatment is related to slightly dehydration of kernel, especially around harvest.

\section{Conclusion}

Based on evolution of observed parameters under water restrictions, it is concluded that RDI treatment $T_{75}$ may be adopted for irrigation of peach tree, allowing a net improvement of WUE and fruit quality without significant reductions in productivity and fruit weight. This water regime may be also adopted for almond tree giving the same production level compared to full irrigation $T_{100}$ and avoiding epidermal wrinkles on almond kernel. However, for plum, the RDI treatment $\mathrm{T}_{50}$ may be adop- 
ted without fear to affect yield and fruit quality. Furthermore, RDI regimes permit to control excessive vegetative growth of trees. The negative effects noted on physiological parameters may be minimized by scheduling restrictions using the curves of SDD values.

\section{Acknowledgements}

Publication cost was supported by the MCA project (USA).

The authors would like to acknowledge the assistance of the technicians: Lahlou Mohammed, Bouichou Lhoussain, Khalfi Chems Doha and Alghoum Mohamed.

\section{REFERENCES}

[1] Anonymous, "Situation de l'agriculture marocaine," Ministry of Agriculture and Marine Fisheries, Morocco, 2011.

[2] A. Agoumi, "Vulnérabilité des pays du Maghreb face aux changements climatiques," International Institute for Sustainable Developement, Manitoba, 2003.

[3] R. Balaghi, M. Jliben, H. Kamil and H. Benaouda, "Etude cadre de l'impact environnemental et social du changement climatique," Institut National de la Recherche Agronomique, Morocco, 2011.

[4] Anonymous, "Les aides financières de l'état pour l'encouragement des investissements agricoles," Ministry of Agriculture and Marine Fisheries, Morocco, 2011.

[5] G. Thivet and M. Blinda, “Améliorer l'efficience d'utilisation de l'eau pour faire face aux crises et pénuries d'eau en méditerranée," Sophia Antipolis, Alpes-Maritimes, France, France, 2007.

[6] P. Vaysse, P. Soing and P. Peyremorte, "L'irrigation des arbres fruitiers," Centre Technique Interprofessionnel des Fruits et Légumes, Paris, 1990.

[7] S. Henry, "Irrigation for the Farm, Garden and Orchard," O. Judd Company, New York, 2010.

[8] L. Stour and A. Agoumi, "Climatic Drought in Morocco during the Last Decades," Hydroécololgie Appliquée, Vol. 16,2008 , pp. 215-232.

[9] M. Azouggagh, "Matériel d'irrigation: choix, utilisation et entretien," Bulletin Mensuel d'Information et de Liaison du Programme National de Transfert de Technologie en Agriculture, No. 81, Rabat, Morocco, 2001.

[10] P. E. Kriedemann and I. Goodwin, "Regulated Deficit Irrigation and Partial Rootzone Drying," Land and Water Australia, Canberra, 2003.

[11] I. Goodwin and A. M. Boland, "Scheduling Deficit Irrigation of Fruit Tree for Optimizing Water Use Efficiency," In: Anonymous, Ed., Deficit Irrigation Practices-FAO Water Reports, Food and Agriculture Organization, No. 22, 2002, pp. 67-78.

[12] M. Kathleen and W. Thomas, "Tree Fruit Irrigation: A Comprehensive Manual of Deciduous Tree Fruit Irrigation Needs," Good Fruit Growers, Wenatchee, 1994.

[13] J. Bretaudeau and Y. Fauré, "Atlas d'arboriculture fruitière," Techniques et Documentation, Paris, Vol. 3, 1991.

[14] E. J. Wickson, "Irrigation in Fruit Growing," Bastian Books,
Toronto, 2008.

[15] J. Girona, M. Mata, A. Arbonès, S. Alegre, J. Rufat and J. Marsal, "Peach Tree Response to Single and Combined Regulated Deficit Irrigation under Shallow Soils," Journal of the American Society for Horticultural Science, Vol. 128, No. 3, 2003, pp. 432-440.

[16] M. Gelly, I. Recasens, J. Girona, M. Mata, A. Arbones, J. Rufat and J. Marsal, "Effects of Stage II and Postharvest Deficit Irrigation on Peach Quality during Maturation and after Cold Storage," Journal of the Science of Food and Agriculture, Vol. 84, No. 6, 2004, pp. 561-568. doi:10.1002/jsfa. 1686

[17] A. Naor, "Irrigation Scheduling of Peach-Deficit Irrigation at Different Phenological Stages and Water Stress Assessment," Acta Horticulturae, No. 713, 2006, pp. 339350.

[18] G. H. Hargreaves, "Defining and Using Reference Evapotranspiration," ASCE Journal of Irrigation Drainage Engineering, Vol. 120, No. 6, 1994, pp. 1132-1139. doi:10.1061/(ASCE)0733-9437(1994)120:6(1132)

[19] E. Fereres, W. O. Pruitt, J. A. Beutel, D. W. Henderson, E. Holzapfel, H. Shulbach and K. Uriu, "ET and Drip Irrigation Scheduling," In: E. Fereres and F. K. Aljibury, Eds., Drip Irrigation Management, Cooperative Extension University of California, 1981, pp. 8-13.

[20] E. Fereres and M. A. Soriano, "Deficit Irrigation for Reducing Agricultural Water Use," Journal of Experimental Botany, Vol. 58, No. 2, 2007, pp. 147-159. doi: $10.1093 / \mathrm{jxb} / \mathrm{erl} 165$

[21] P. Monney and E. Bravin, "Irrigation des arbres fruitiers," Station de Recherche Agroscope Changins-Wadenswil ACW, Nyon, 2010.

[22] J. Lichou, “Abricot: les variétés, mode d'emploi," Centrex, Paris, 1998.

[23] K. M. Maib, P. K. Andrews, G. A. Lang and K. Mullinix, "Tree Fruit Physiology: Growth and Development: A Comprehensive Manual for Regulating Deciduous Tree Fruit Growth and Development," Good Fruit Growers, Wenatchee, 1996.

[24] C. Hilaire, P. Giauque, V. Mathieu, P. Soing, A. Osaer, D. Scandella, J. Lichou, F. Maillard and C. Hutin, "Le pêcher," Centre Technique Interprofessionnel des Fruits et Légumes, Paris, 2003.

[25] A. Battilani, "Regulated Deficit of Irrigation Effects on Growth and Yield of Plum Tree," Acta Horticulturae, No. 664, 2004, pp. 55-62.

[26] A. Mahhou, T. M. Dejong, T. Cao and K. S. Shackel, "Water Stress and Crop Load Effects on Vegetative and Fruit Growth of 'Elegant Lady' Peach [Prunus persica (L.) Batch] Trees," Fruits, Vol. 60, No. 1, 2005, pp. 5568. doi:10.1051/fruits:2005013

[27] C. Granier, D. Inzé and F. Tardieu, "Spatial Distribution Cell Division Rate Can Be Deduced from That of P34 Kinase Activity in Maize Leaves Grown in Contrasting Conditions of Temperature and Water Status," Plant Physiology, Vol. 124, No. 3, 2000, pp. 1393-1402. doi: $10.1104 / \mathrm{pp} .124 .3 .1393$

[28] D. J. Coscrove, "Growth of the Cell Wall," Molecular 
Cell Biology, Vol. 6, No. 11, 2005, pp. 850-861.

[29] O. Bouchabke, F. Tardieu and T. Simounno, "Leaf Growth and Turgor in Growing Cells of Maize (Zea mays L.) Respond to Evaporative Demand in Well-Watered But Not in Water Saturated Soil," Plant, Cell and Environment, Vol. 29, No. 6, 2006, pp. 1138-1148. doi:10.1111/j.1365-3040.2005.01494.x

[30] F. Tardieu, P. Cruiziat, J. L. Durand, E. Triboi and M. Zivy, "Perception de la sécheresse par la plante, conséquences sur la productivité et sur la qualité des produits récoltés," In: sécheresse et agriculture, Ed., Unité ESCo. INRA, Paris, 2006, pp. 49-67.

[31] R. Kauser, H. R. Athar and M. Ashraf, "Chlorophyll Fluorescence: A Potential Indicator for Rapid Assessment of Water Tolerance in Canola," Pakistan Journal of Botany, Vol. 38, No. 5, 2006, pp. 1501-1509.

[32] B. Bojovié and A. Markovié, "Correlation between Nitrogen and Chlorophyll Content in Wheat (Triticum aestivum L.)," Kragujevac Journal of Science, No. 31, 2009, pp. 69-74.

[33] D. Luquet, A. Vidal, J. Dauzat, A. Begue, A. Olioso and P. Clouvel, "Using Directional Tir Measurements and 3d Simulations to Assess the Limitations and Opportunities of Water Stress Indices," Remote Sensing of Environment, Vol. 90, No. 1, 2004, pp. 53-62. doi:10.1016/j.rse.2003.09.008

[34] L. Helyes, Z. Pek and B. Mcmicheal, "Relationship between Stress Degree Day Index and Biomass Production and the Effect and Timing of Irrigation in Snap Been (Phaseolus vulgaris. Var. Nanus) Stands: Result of a LongTerm Experiments," Acta Botanica Hungarica, Vol. 48, No. 3-4, 2006, pp. 311-321. doi:10.1556/ABot.48.2006.3-4.6

[35] T. Sotiropoulos, D. Kalfountzos, I. Aleksiou, S. Kotsopoulos and N. Koutinas, "Response of a Clingstone Peach Cultivar to Regulated Deficit Irrigation," Scientia Agricola, Vol. 67, No. 2, 2010, pp. 164-169. doi:10.1590/S0103-90162010000200006

[36] A. M. Boland, P. H. Jerie, P. D. Mitchell and I. Goodwin, "Long-Term Effects of Restricted Root Volume and Regulated Deficit Irrigation on Peach: II. Productivity and Water Use," Journal of the American Society for Horticultural Science, Vol. 125, No. 1, 2000, pp. 143-148.

[37] D. J. Chalmers, P. D. Mitchell and L. Van Heek, "Control of Peach Tree Growth and Productivity by Regulated Water Supply, Tree Density and Summer Pruning," Jour- nal of the American Society for Horticultural Science, No. 106, 1981, pp. 307-312.

[38] P. D. Mitchell and D. J. Chalmers, "The Effect of Reduced Water Supply on Peach Tree Growth and Yields," Journal of the American Society for Horticultural Science, No. 107, 1982, pp. 853-856.

[39] M. Valverde, R. Madrid and A. L. Garcia, "Effect of the Irrigation Regime, Type of Fertilization, and Culture Year on the Physical Proprieties of Almond (cv. Guara)," Journal of Food Engineering, Vol. 76, No. 4, 2006, pp. 584 593. doi:10.1016/j.jfoodeng.2005.06.009

[40] D. A. Goldhamer, E. Fereres and M. Salinas, "Can Almond Trees Directly Dictate Their Irrigation Needs," California Agriculture, Vol. 57, No. 4, 2003, pp. 138-144. doi:10.3733/ca.v057n04p138

[41] J. Girona, M. Mata and J. Marsal, "Regulated Deficit Irrigation during the Kernel-Filling Period and Optimal Irrigation Rates in Almond," Agricultural Water Management, Vol. 75, No. 2, 2005, pp. 152-167. doi:10.1016/j.agwat.2004.12.008

[42] I. F. Garcia-Tegero, V. H. Duràn-Zuazo, L. M. Vélez, A. Hernàndez, A. Salguero and J. L. Muruel-Fernàndez, "Improving Almond Productivity under Deficit Irrigation in Semiarid Zones," The Open Agriculture Journal, No. 5, 2011, pp. 56-62. doi:10.2174/1874331501105010056

[43] D. S. Intrigliolo and J. R. Castel, "Performance of Various Water Stress Indicators for Prediction of Fruit Size Response to Deficit Irrigation in Plum," Agricultural Water Management, Vol. 83, No. 1, 2006, pp. 173-180. doi:10.1016/j.agwat.2005.12.005

[44] B. D. Lampinen, K. A. Shackel, S. M. Southwick, B. Olson and J. T. Yeager, "Sensitivity of Yield and Fruit Quality of French Prune to Water Deprivation at Different Fruit Growth Stage," Journal of the American Society for Horticultural Science, Vol. 120, No. 2, 1995, pp. 139140.

[45] D. J. Chalmers, P. D. Mitchell and P. H. Jerie, "The Relation between Irrigation, Growth and Productivity of Peach Tree," Acta Horticulturae, No. 173, 1985, pp. 283-288.

[46] M. Gelly, I. Recasens, M. Mata, A. Arbones, J. Rufat, J. Girona and J. Marsal, "Effect of Water Deficit during Stage II of Peach Fruit Development and Postharvest on Fruit Quality and Ethylene Production," Journal of Horticultural Science and Biotechnology, Vol. 78, No. 3, 2003, pp. 324-330. 